\title{
おやつ昆布の嚙みにくさと力学特性
}

\author{
神山かおる*・畠山英子** ・小林知子** ・八城正典 ${ }^{* * *}$ \\ 東 輝明 $* * * *$ 境 知子* ・ 鈴木建夫*
}

\section{Masticatory difficulty and mechanical characteristics of kelp snacks}

\author{
Kaoru Kohyama*, Eiko Hatakeyama**, Satoko Kobayashi**, Masanori Yashiro***, \\ Teruaki Azuma ${ }^{* * *}$, Tomoko Sakar*, Tateo Suzuki* \\ * National Food Research Institute, 2-1-2 Kannondai, Tsukuba, Ibaraki 305-8642 \\ ** Kansei Fukushi Research Center, Tohoku Fukushi University, 6-149-1 Kunimigaoka, \\ Aoba-ku, Sendai, Miyagi 989-3201 \\ ${ }^{* * *}$ Maejima Food Co. Ltd., 655 Hiratsu, Yoneda, Kakogawa, Hyogo 675-0054 \\ ${ }^{* * * *}$ RETS Division, Nitta Corporation, Sensor Development Project, 4-4-26 Sakuragawa, \\ Naniwa-ku, Osaka, 556-0022
}

\begin{abstract}
Tensile test, sensory evaluation, electromyography and masticatory pressure measurement of kelp snack were carried out in order to clarify the characteristics as a functional food for mastication training. Though no difference can be detected in breaking stress of kelp samples used in the present study, breaking force is different according to their thickness. In the sensory evaluation, it was judged that the samples with a high breaking force were difficult to masticate. In the electromyography, the sample judged difficult to masticate showed long mastication time, many number of chewing strokes, and high total muscle activity needed until swallowing. In the meantime, there was no significant difference among the samples in masticatory force, contact area, and masticatory pressure in the first chew. It is considered that mechanical characteristics of the samples with higher breaking stress than masticatory pressure influence total masticatory behavior but don't affect the first chew of human.

(Received Mar. 10, 2000 ; Accepted Aug. 8, 2000)
\end{abstract}

\section{は じめに}

近年, 軟らかい食品が増えたために，若者の咀嚼能力 が未発達なのではないかと問題視されている先，伝統的 な日本の食事では, 食物䋐維がふんだんに含まれ, 每日 の食生活の中で自然に咀嚼能力が鍛えらていたと考えら れるが, 現代の, 特に若者の好むものの中には咀嚼を多 く必要とする食品が少ない.

咀嚼訓練のために, 人工食品すなわち, チューインガ $ム^{3.5)}$ やコンニャクマンナンシート1) 用いて咀嚼力の
増強が図られてもいるが，日常食品を嚙むことによっ て，咀嚼能力が高まる方が望ましいのは言うまでもな い．昆布は，ミネラル源として重要な食品であるだけで なく，咀嚼を多く必要とし，甘味やカロリーが少ない上 いう点で，咀嚼訓練に向いている11. 若者に利用されや すいコンビニエンスストア等で，手軽に購入でき，おや つとして食べられる形態にできれば，咀嚼機能食品とし ても有望であると考えられる.

咀嚼を機能として考えるとき，嚙みにくさを何らかの 数値表現する必要がある。咀嚼を運動としてとらえれ

* 農林水産省食品総合研究所（†305-8642 茨城県つくば市観音台 2-1-2）

** 東北福祉大学感性福祉研究所（干989-3201 宮城県仙台市青葉区国見ヶ 丘 6-149-1）

*** 前島食品株式会社（宁675-0054 兵庫県加古川市米田町平津 655）

**** 二ッ夕株式会社 RETS 事業部（干556-0022 大阪府大阪市浪速区桜川 4-4-26） 
ば，咀嚼に要する筋肉の活動量の総和が高いもの 嚙みにくい食品と考えられる。これは咀嚼筋筋電位の時 問積分值を求めて見樍もられる.

今まで同一種の食品について嚙みにくさの差異を筋電 位計測から客観的数值で論じた例は少ない，一定重量ま たは体積のゼリー8), 肉 ${ }^{9-11)}$, ビスケット ${ }^{12)}$, 米飯 ${ }^{13)}$ 等で の報告があるが，䋐維の多い植物性食品では皆無であ る.ここでは，おやつ昆布の嚙みにくさに関係する力学 的性質が何かを明らかにするために，力学物性の機器測 定, 官能評価, 咀嚼筋筋電位ならびに咀嚼圧計測を行っ た.

\section{実 験 方 法}

\section{1. 昆布試料}

原藻は 1998 年 8 月下旬加 10 月上旬に採取された岩 手県産ホソメコンブ (Laminaria religiosa Miyabe) の 長切 2 等扔よび 4 等である. ソルビトールおよびアミ， 酸等を含む調味液で味付け後乾燥し，一ワサイズに切断 した. 水分は $12.0 \%$ (常生加熱乾燥法, $105^{\circ} \mathrm{C} 2$ 時間), 食 塩相当量は $8.4 \%$ (モール法)であった。

\section{2. 昆布の分類}

昆布は一回で咀嚼・舆下が容易に行える大きさ，すな わち繊維方向の長さ $45 \mathrm{~mm} \times$ 幅 $9.5 \mathrm{~mm}$ とした。一枚ず つ重量を量り, I $(0.20 \pm 0.03 \mathrm{~g}), \quad$ II $(0.27 \pm 0.03 \mathrm{~g}), \quad$ III $(0.35 \pm 0.04 \mathrm{~g}) ， \mathrm{IV}(0.45 \pm 0.05 \mathrm{~g})$ に分類した，被験者は 見ただけ，または一枚を持っただけでは，どの試料か判 別することは難しい.

\section{3. 力学特性の測定}

インストロン 5542 型引っ張り圧縮試験機を用いて, 初期の引っ張り用チャック間距離が $10 \mathrm{~mm}$ になるよう に試料を装着し，㵶維方向に $10 \mathrm{~mm} / \mathrm{min}$ で等速で引っ 張り破断させた。試験温度は常温 $\left(25^{\circ} \mathrm{C}\right)$ とした。

\section{4. 官能試験}

健康な 20 代の男女学生 5 名ずっ（平均年齢 23.1 歳） に 4 種の昆布をランダムな順番で与え，4種類を食べ終 わった後に嚙みにくさを順位法で答えさせた。

\section{5. 筋電位計測}

官能試験と同一の被験者とし，実験の目的や計測手法 について十分説明を行った，左右の咬筋および側頭筋前 腹上の表面に，脳波用.而状電極を張り付け，咀嚼中の筋 電位を記録した（図 1)。屁布式料はランダムな順で与 え，どの試料も 3 回ずつ，計 12 試料在被験者が疲れない ようにインターバルを取って計测した，被験者には試料 種類を伏せ，普通に咀嚼し，嚥下させるようにした。

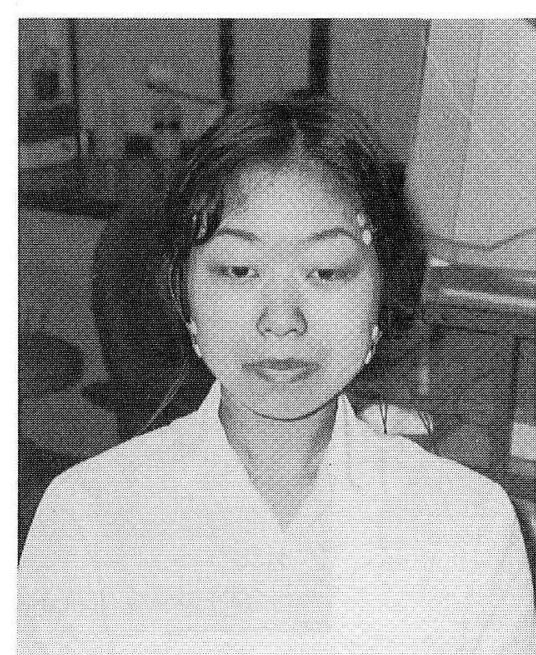

Fig. 1 Position of electrodes for electromyography measurement

The electromyographic activities are measured with surface electrodes attached on left and right anterior tempolar and masseter muscles.

ンプ（日本光電 MEG-6108）で堌幅した筋電位は, チャートレコーダとDAT（ソニーPC 208 A）上に記録 し, $500 \mathrm{~s}^{-1}$ で AD 变換後, 嚥下までの咀嚼回数, 咀嚼㭙 間及び筋活動量を前報 ${ }^{13)}$ に準じて解析した。

\section{6. 咀嚼圧計測}

咀嚼圧は、ニッタ社 ISCAN $10 \times 10$ システムを用いて 測定した．センサは，図 2 に示すように，1個 $1.27 \mathrm{~mm}$ 角の感生セルが 10 行 $\times 10$ 列に配置された, 厚さ $0.1 \mathrm{~mm}$ 以下のプラスチックシート状で，飽和圧約 $4 \mathrm{MPa} の も$ のを,インストロン試験機で既知荷重を与えてキャリブ レーション後に用いた。 シートセンサ以外は既報 ${ }^{14,15)}$ 之 同じシステムである，試料はセンサの感圧面の大きさに 合わせ，䋐維方向に長さ $15 \mathrm{~mm} \times$ 幅 $9.5 \mathrm{~mm}$ に切った。 被騃者は健康な成人女性 11 名（平均年齢 32.5 歳，21 50 歳)で，昆布をセンサシートの感圧面に固定し，嚙み やすい側の第一大臼歯付近に当て，咀嚼させた，第一回 目の咀嚼動作中に昆布試料下の各感圧点にかかる圧力を $200 \mathrm{~s}^{-1}$ で計测した。

\section{実 験 結 果}

\section{1. 昆布の力学特性}

表 1 に昆布の形状求よび引っ張り試験結果を示す。試 


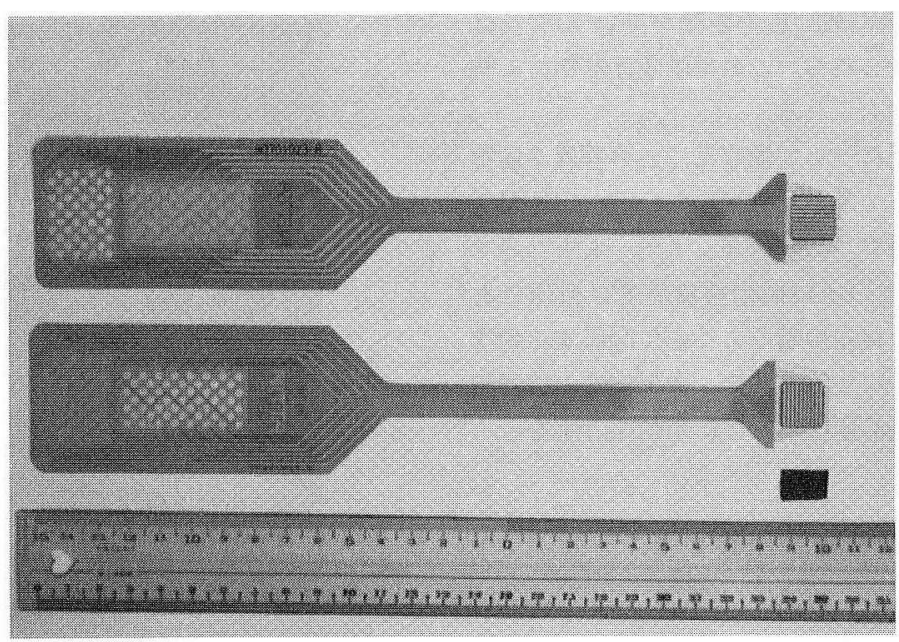

Fig. 2 Iscan $10 \times 10$ sheet sensors

10 rows printed on top side and 10 columns on reverse side with $1.27 \mathrm{~cm}$ pitch make 100 sensing points. A kelp sample for the Iscan test is shown beside the sheet.

Table 1 Size and tensile test results for kelp samples

\begin{tabular}{lcccc}
\hline \hline \multicolumn{1}{c}{ Parameter } & Sample I & Sample II & Sample III & Sample IV \\
\hline Weight $(\mathrm{g})$ & $0.201^{\mathrm{a}} \pm 0.005$ & $0.272^{\mathrm{b}} \pm 0.006$ & $0.338^{\mathrm{c}} \pm 0.007$ & $0.457^{\mathrm{a}} \pm 0.008$ \\
Width $(\mathrm{cm})$ & $0.956^{\mathrm{a}} \pm 0.018$ & $0.956^{\mathrm{a}} \pm 0.024$ & $0.956^{\mathrm{a}} \pm 0.02$ & $0.956^{\mathrm{a}} \pm 0.014$ \\
Thickness $(\mathrm{mm})$ & $0.34^{\mathrm{a}} \pm 0.01$ & $0.48^{\mathrm{b}} \pm 0.02$ & $0.59^{\mathrm{c}} \pm 0.03$ & $0.76^{\mathrm{d}} \pm 0.02$ \\
Breaking force $(\mathrm{N})$ & $40.16^{\mathrm{a}} \pm 2.58$ & $54.88^{\mathrm{a}} \pm 4.33$ & $73.91^{\mathrm{b}} \pm 4.47$ & $90.37^{\mathrm{b}} \pm 6.48$ \\
Breaking stress $(\mathrm{MPa})$ & $12.29^{\mathrm{a}} \pm 0.75$ & $12.1^{\mathrm{a}} \pm 1.12$ & $13.27^{\mathrm{a}} \pm 0.77$ & $12.37^{\mathrm{a}} \pm 0.65$ \\
Breaking strain & $0.71^{\mathrm{a}} \pm 0.05$ & $0.87^{\mathrm{a}} \pm 0.10$ & $0.86^{\mathrm{a}} \pm 0.04$ & $0.87^{\mathrm{a}} \pm 0.08$ \\
\hline
\end{tabular}

Mean士standard error

Values not followed by a common letter are significantly different $(\mathrm{P}<0.05)$ in a row performed with Tukey test.

料 I 〜 IVの重量は分散分析の結果，それぞれ有意に異な り $(\mathrm{P}<0.01)$, 個々の昆布重量は厚さに比例した $(\mathrm{n}=60$ で相関係数 $\mathrm{r}=0.869)$. 引っ張り破断荷重は $\mathrm{I}<\mathrm{II}<\mathrm{II}$ くIVで有意差は I とI，III とIVのグループ間にあった. 厚さが破断荷重の順に大きくなるため, 破断荷重を初期 断面積で割った破断応力にも，破断伸びを初期長で割っ た破断歪みにも分散分析結果に有意な差が認められな かった。

\section{2. 官能試験}

最も嚙みやすいものを 1 点, 嚙みにくいものを 4 点と して，10人の被験者による啮みやすさの順位和は， I が 11, Iが 22.5, IIIが31.5, IVが 35 であった，Freidman 検定では，試料間に $\mathrm{P}<0.01$ で有意差が認められた。各
試料間の差を明らかにするためWilcoxon の符号付き 順位検定を行うと，P<0.01で I と III が， P<0.05で I と II，IとIVが有意に異なったが，【とII， IIIとIVの間に は有意差がなかった。

\section{3 . 筋電図}

図 3 に代表的筋電図を示す。咬筋, 側頭筋共に，下顎 を閉じる閉口筋であり，4筋が食品を嚙んでいる時に同 時に活動するのが観察された。 また，左で嚙んでいると きは, 左側の筋電位が強く出る傾问にあり, 咀嚼側の筋 肉活動が優勢であった，筋肉によってバーストの大きさ は晎なるが, 咀嚼初期から後期までの間, 顕著な大きさ の变化は観察されなかった４筋のバースト部の面積を 全咀嚼回数にわたって加えたものを, 咀嚼に要した筋肉 


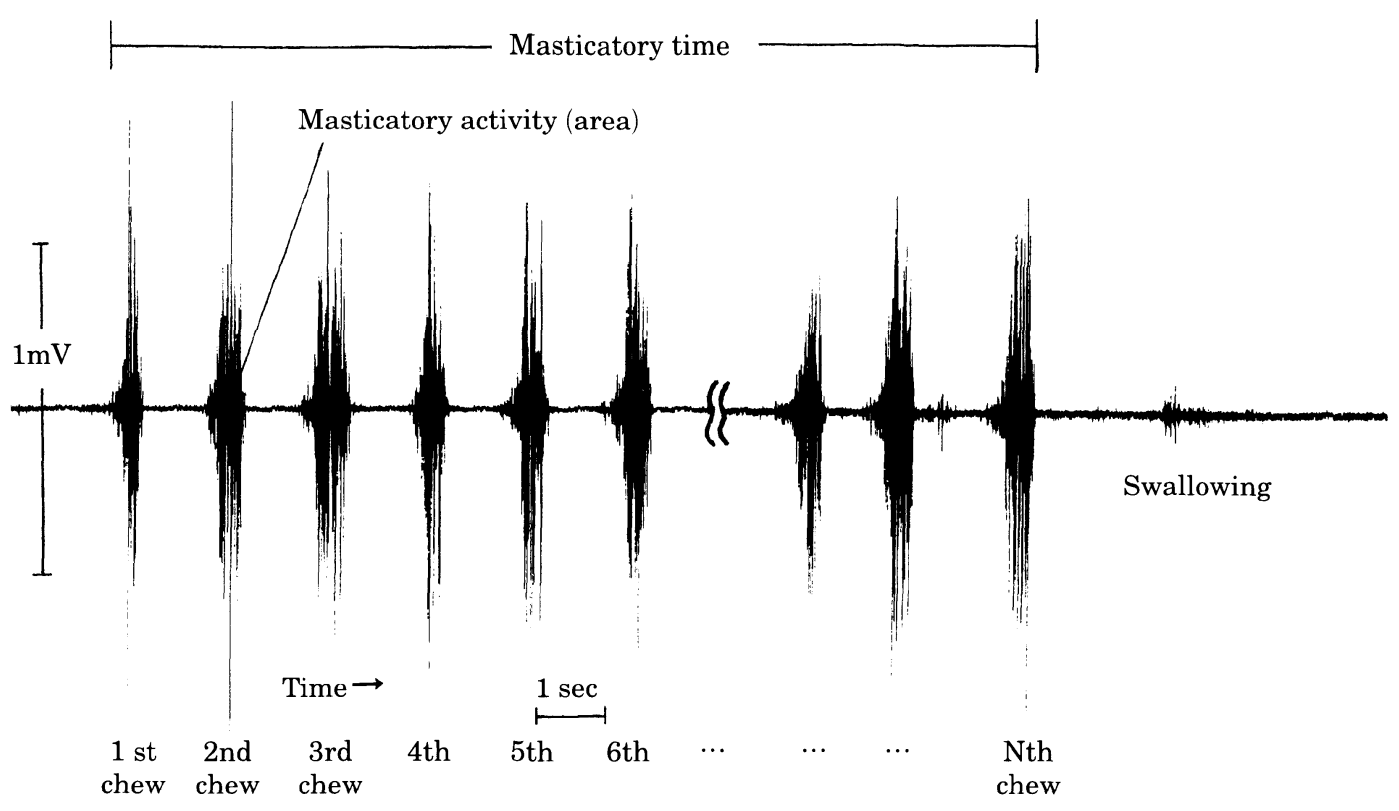

Number of chewing strokes $=\mathrm{N}$

Fig. 3 An example of electromyogram

Masticatory time, number of chewing strokes and total masticatory activities are determined.

の活動量と考えた.

個人差は大きく，例えば試料 I は 3 回の平均咀嚼時間 が, 最小の被験者で 16.0 秒, 最大で 77.0 秒, 10 名の平均 で 31.5 秒であった。咀嚼時間と咀嚼回数は高い相関を示 し（相関係数 $\mathrm{r}=0.958 ） た ．$ 全筋活動量とこれらの変数 とも相関（咀嚼時間とは $\mathrm{r}=0.644$, 咀嚼回数とは $\mathrm{r}=$ 0.712，いずれも $\mathrm{P}<0.001 ）$ がみられた。 表 2 に示す通 り， 3 変数之屯 I $<\mathrm{II}<\mathrm{III}<\mathrm{IV}$ の順に増加し，官能評価 と同様に，III こIVには有意な差が見られなかった。

\section{4. 咀嚼圧}

最大咀嚼力および感圧面積，最大咀嚼圧すなわち最大 咀嚼力/感圧面積を求めた. 筋電図パラメー夕と同様, 全 変数について個人差が大きかった．また，I I II $<$ III $<$ IVの順にはならず, 力学特性や官能評価, 筋電図結果之 の対応が説明できなかった。試料之被験者の交互作用が 認められることから，試料の力学的性質に由来する差と は言えないと考えられた。しかし，昆布を咀嚼する場合， 平均して $100 \mathrm{~N}$ （最小 32 -最大 $222 \mathrm{~N}$ ） の咀嚼力, 0.75 $\mathrm{cm}^{2}\left(0.49-1.02 \mathrm{~cm}^{2}\right)$ の感圧面積, $1.36 \mathrm{MPa}(0.65-2.15$ $\mathrm{MPa}$ ）の最大咀嚼压が観測された。

Table 2 Electromyographic parameters of kelp samples

\begin{tabular}{ccccc}
\hline \hline Parameter & Sample I & Sample II & Sample III & Sample IV \\
\hline Masticatory time (sec) & $31.51^{\mathrm{a}} \pm 3.16$ & $36.92^{\mathrm{b}} \pm 2.52$ & $48.72^{\mathrm{c}} \pm 4.20$ & $50.52^{\mathrm{c}} \pm 3.32$ \\
min $-\max$ & $16.03-76.97$ & $26.13-63.00$ & $35.33-108.33$ & $35.43-90.13$ \\
Number of chewing strokes & $46.30^{\mathrm{a}} \pm 4.29$ & $53.17^{\mathrm{a}} \pm 3.62$ & $70.63^{\mathrm{b}} \pm 5.57$ & $72.00^{\mathrm{b}} \pm 4.54$ \\
min $-\max$ & $28.00-98.67$ & $30.33-79.00$ & $40.00-139.00$ & $44.33-107.33$ \\
Total masticatory activities $(\mathrm{mV} \cdot \mathrm{s})$ & $3.796^{\mathrm{a}} \pm 0.295$ & $5.044^{\mathrm{b}} \pm 0.421$ & $6.520^{\mathrm{c}} \pm 0.465$ & $7.040^{\mathrm{c}} \pm 0.500$ \\
$\min -\max$ & $1.692-5.85$ & $2.028-8.867$ & $3.270-9.976$ & $3.397-10.532$ \\
\hline
\end{tabular}

Mean \pm standard error and minimum-maximum values of 10 subjects.

Mean values not followed by a common letter are significantly different $(\mathrm{P}<0.05)$ in a row performed with Tukey test. 


\section{考察}

昆布は硬く一度の咀嚼では嚙み切れず，何回も繰り返 し咀嚼することによって，燕下可能な状態になる．今回 用いた試料では，もっとも嚙みやすいと判定されたIで も，平均して 46.3 回の咀嚼を要した。破断荷重が 40.2 $90.4 \mathrm{~N}$ という值は，最大咀嚼力 $100 \mathrm{~N}$ よりも低い。昆布 について咀嚼力の実測例は見あたらないが，歯や義歯に 歪みゲージ等を装着して, 様々な食品の咀嚼中に測定さ れた歯に働く力は, 20〜 $150 \mathrm{~N}$ 程度であり ${ }^{16-21)}$, 軟らかい 食品では低く嚙みにくい食品では高くなる，昆布が嚙み 切りにくいことを考えれば，実測値 $100 \mathrm{~N}$ は妥当である と思われる。一方，実際に昆布之歯が接触している面積 を考慮に入れた最大咀嚼圧は平均 $1.36 \mathrm{MPa}$ であり, 引っ張り破断応力 $12.1 \sim 13.3 \mathrm{MPa}$ に比べて，大幅に低 かった，昆布は約 $100 \mathrm{~N}$ の力をかけると，緎維方向に 引っ張れば破断できるが，咀嚼のように繊維とほぼ直角 に昆布表面積方向に広く作用させる場合は破断できな い，その上，臼歯の形状は平らではなく，平均感圧面積 $0.75 \mathrm{~cm}^{2}$ が采す通り，昆布表面全体にまんべんなく力を 加えることはできない. 平均的には破断応力に比較して 低い圧力しかかからず，さらに全く圧がかからない部分 も存在することから，咀嚼においては，どんな被験者で あ 10 回以内の咀嚼で昆布を破断することはできなかっ たと考えられる.

ここで用いた 4 種の昆布試料について, 力学特性值, すなわち破断荷重の $\mathrm{I}<\mathrm{II}<\mathrm{III}<\mathrm{IV}$ を反映するのは，燕 下までに必要な時間に関する変数である, 咀嚼時間, 咀 嚼回数, 咀嚼筋の全活動量であった。これらの变数は互 いに相関し，官能評価でむ，咀嚼を長く要するような試 料を, 踤みにくいと感じた。筋電位計測が必要な, 燕下 までに要する全筋活動量に対し，咀嚼回数や咀嚼時間を 計測するのは容易である. 咀嚼回数または咀嚼時間の計 測により，筋電位等の生体計測を行わなくても，咀嚼し やすさを見積もることができるのではないかと考えられ る.

昆布一枚当たりの咀嚼時間, 回数, 咀嚼箭全活動量は, 互いに相関し，重量や厚さの高いIV > III > II > I の順で あった。一方, 昆布重量当たりの咀嚼時間, 回数, 咀嚼 筋活動量の総和は， I > II ・ III > IVの順である．嚙み切 ることを重視し厚さ当たりでも計算したが，IVが最小と なり重量当たりの場合と似た傾向であった。すなわち, 同じ栄養価ならば，咀嚼量は薄い昆布を多数食べた方が 多くなる，昆布のように嚙みにくい試料においては，一
口量を小さくしても嚙まないで丸飲みしてしまう恐れは ない. 薄い昆布の方が，同一量を䝮取するための咀嚼活 動は増加し，咀嚼訓練にはより効果的と言えよう。

見ただけでは嚙みにくさが違うことがわからない 4 種 の昆布を 1 回目に嚙むとき，被験者は過去に昆布を食べ た経験により約 $100 \mathrm{~N}$ の力を出したよ思われる.1 回目 の咀嚼圧に試料差が現れなかったのは，1嚙み目に試料 の嚙みにくさが認知できなかったからではないかと推定 される。あるいは，破断時の圧力減少が咀嚼曲線に現れ る，容易に破断される食品と異なり，昆布のように嚙み 切りにくい食品においては，咀嚼圧が試料の破断荷重に 影響されないと屯考えられる。

咀嚼中に，昆布は唾液と混合して軟化し，徐々に形状 も崩れてゆく，燕下時までに力学特性は大きく変化する のは明らかである。そのため，咀嚼初期に最も試料の力 学特性が顕著に現れると考えられたが，筋電位も咀嚼圧 も個人差に比べて試料間差は小さかった。試料間差がな かった破断応力や破断歪みが生体計測による变数に関連 している可能性ああるが，咀嚼の長さが破断荷重と対応 があったことは, 咀嚼が昆布の力学特性によって変化し たことを示している，昆布は，少数回の咀嚼では嚙み切 れないため，破断荷重に相当する变数が咀嚼初期の生体 計測からは得られなかったのではないかと推察してい る、咀嚼筋の強さや歯の形状等の個人差が計測値の大き な差を生じる原因となっているのだろうが，個人の咀嚼 能力にも関わる重要な問題と考えられるので, 昆布の咀 嚼計測値と咀嚼能力との関係については別途発表す $3^{22)}$.

\section{要 約}

おやつ昆布の咀嚼機能食品としての特性を明らかにす るために，引っ張り試験機による破断測定，官能評価， 咀嚼筋筋電位ならびに咀嚼压計測を行った。 今回用いた 4 種の昆布では，破断応力は変化しないが，厚みが異な るため，破断荷重は異なった。官能評価では，破断に大 きな力を要したものが嚙みにくいと判断された，筋電位 計測では，嚙みにくいと判断された試料では，咀嚼時間 や咀嚼回数, 全咀嚼筋活動量が大きくなった，尼布のよ うに咀嚼压より屯高い破断応力をもつ試料の力学特性 は，ヒトの燕下までの咀嚼挙動に影響し，破断荷重の高 い試料を，ヒトは咀嚼回数を多くし，長時間をかけて咀 嚼し，嚙みにくいと感じることが示唆された。一方，一 回目の咀嚼に要する咀嚼圧や感厷面積等には, 試料の力 学特性の影響は観られなかった。 
本研究は科学技術庁生活社会ニーズ研究の助成金に よって行われた。 また文部省学術フロンティア推進事業 研究費の一部を使用した。咀嚼実験に参加されたボラン ティアに感謝する.

\section{文献}

1）河村洋二郎, 堀尾 強：歯基礎誌， 31，281 (1989).

2）岸田典子：日咀嚼誌，5，21（1995).

3) Tzakis, M.G., Kiliaridis, S. and Carlsson, G.E. : Acta Odont. Scand., 47, 355 (1989).

4）小野芳明・干 昉・飯島英世 - 三輪全三 - 柴田柾 樹: 口病誌，59，512(1992).

5）菅原準二・賓 広道・原之屯子・藤井智己・三谷 英夫・川村 仁・石川久史：日咀嚼誌， 3, 67 (1993).

6）塩野幸一・甲斐正子・丸田裕子・旭爪伸二・小椋 正 : 口腔衛生誌, 36, 179 (1986).

7）柳沢幸江・田村厚子 - 寺元芳子 - 赤坂守人：小児 歯誌, 27, 74 (1989).

8）塩野幸一・清水久喜 - 小椋 正 - 規工川浩 : 小児 歯誌, 28, 1036 (1990).

9) Duizer, L.M., Gullett, E.A. and Findlay, C.J. : J. Sensory Studies, 9, 33 (1994).
10) Mathevon, E., Mioche, L., Brown, W.E. and Culioli, J. : J. Texture Studies, 26, 175 (1995).

11) Braxton, D., Dauchel, C. and Brown, W.E. Food Quality and Preference, 7, 217 (1996).

12) Brown, W.E., Langley, K.R. and Braxton, D. : J. Texture Studies, 29, 481 (1998).

13) Kohyama, K., Ohtsubo, K., Toyoshima, H. and Shiozawa, K.:J. Texture Studies, 29, 101 (1998).

14) Kohy ama, K., Nishi, M. and Suzuki, T. : J. Food Sci., 62, 922 (1997).

15) Kohy ama, K. and Nishi, M. : J. Texture Studies, 28, 605 (1997).

16) Yurkstas, A. and Curby, W.A. : J. Prosthet. Dent., 3, 82 (1953).

17) Anderson, D.J. : J. Dent Res., 32, 785 (1953).

18）三浦不二夫・角田正明：口歯医師会誌，7，293 (1954).

19）坂東永一：医用電子と生体工学，7，15（1969）.

20）高橋渖子 · 中沢文子 : 家政誌，38，107（1987）.

21) Michael, C.G., Javid, N.S., Colaizzi, F.A., Gibbs, C.H. : J. Prosthet. Dent., 63, 549 (1990).

22）神山加る・畠山英子・小林知子・関 哲哉・滝 口俊男・鈴木建夫 : 日咀嚼誌, 10,41（2000）。

(平成 12 年 3 月 10 日受付，平成 12 年 8 月 8 日受理) 